\title{
Banking Services and Customers Bank Selection Criteria (Evidence from Ethiopian Commercial Banks in Addis Ababa)
}

\author{
Mr. Ismael Hussein Malela \\ Lecturer and Researcher in the Department of Accounting and finance \\ College of Business and Economics, Oda Bultum University, Chiro, West Hararge Zone, Oromia, Ethiopia
}

\begin{abstract}
To design a suitable marketing strategy to keep existing customers and for attracting new ones, commercial banks need to identify the criteria on which customers determine their bank choice decision. Hence, the purpose of this study is to examine the significance of bank selection criteria and how customers rank the factors based on their importance level to prioritize banks and banking services. It also intends to present an analysis of gender differences on the relative importance of choice criteria in respect of selecting a bank and to bring about the opinion of customers on any extra services needed to be offered by banks. Both quantitative and qualitative methodologies are used, Based on responses given by 201 customers in Addis Ababa city from different occupations (students, employees, and businessmen), is employed in the analysis. A non-probability convenience sampling was also used. The finding from this study reveals that there are two most important bank selection criteria for customers are "convenience" and "service provision" for the entire customers while it is "bank's image" is the second most important factor for male customers. On the other hand, the least two important factors of bank selection for customers are "financial benefits/ technology", "reputation" and "promotion strategy" and "attractiveness" for female customers. Finally, it is recommended that hierarchical information integration is a potentially useful method for bank managers to study complex decision-making problems such as bank choice.
\end{abstract}

Keywords: Bank selection criteria, Customers, Banks, and Banking service.

DOI: $10.7176 / \mathrm{JMCR} / 83-03$

Publication date: December $31^{\text {st }} 2021$

\section{Introduction}

The banking industry has been characterized by increasing competition since the early 1980s (Blank son et al., 2017). This has been the result of several interrelated factors such as competition and deregulation that have revolutionized the distribution of many financial services. In other words, an increased competition resulting from a decade of deregulation of the financial services industry has meant that banks find themselves faced with the task of differentiating their organizations and their offerings as a means of attracting customers (Blank son et al., 2017).

The concept of how customers choose banks has been given considerable attention by researchers (for example Blank son et al., 2017; Mokhlis, 2009; Mylonakis, 2007; Wing, 1997; Boyd et al., 1994 and Almossawi, 2001). Exploring such information will assist banks to recognize the appropriate marketing strategies needed to attract new customers and retain existing ones (Kayak and Kucukemiroglu, 1992).

In Ethiopia, Modern banking was introduced in 1905. At the time, an agreement was reached between emperor Menelik II and a representative of the British-owned national bank of Egypt to open a bank which leads to the bank of Abyssinia being launched on Feb. 16, 1906, by the emperor (Abraham et al. 2015). This event marked the introduction of banking in the country.

Ethiopian banking is flourishing. Financial Results for the 2018 fiscal year prove an industry enjoying high growth, high profits, and high dividends. Even in the middle of a challenging situation, all key areas of banking operations: collecting deposits, providing loans, and foreign exchange dealing showed growth of more than 20 percent. Even though sharing strong expansion, there are of course prominent variations along with banks in terms of their aggregate size, revenue sources, customer focus, loan concentration, and operational efficiency. Presently, there are 15 banks in Ethiopia of which 12 are private banks and the rest are government-owned banks. Moreover, looking ahead, banks will surely be confronted by the entry of six new banks (namely: Gada, Hijra, Hawassa, Hosana, Noah, Zam-zam) and other financial institutions.

With growing competitiveness in the banking industry (Grady and Spencer, 2010), and the similarity of services offered by banks (Holstius and Haynak, 2015), it has become increasingly important that banks identify the factors that determine the basis upon which customers choose between providers of financial services. In this regard, the basic aim of the study is to examine the basic motivational factors in customers ${ }^{\text {ee }}$ bank selection in Addis Ababa city.

\section{Statement of the problem}

Many studies have been undertaken to analyze factors that affect customers' preferences in banking services. 
Among these studies include Mokhlis et al. (2018) who examined the determinants of bank selection criterion in Malaysia considering undergraduate students; in Bahrain (Almossawi, 2011), a case of college students and other studies are also undertaken in Europe (Bosnia\&Herzegovina by Cicic et al., 2013; Greek by Mylonakis, 2017) and Africa (Ghana by Blankson et al., 2017; Nigeria by mariachi et al., 2010; Maiyaki, 2011) countries on the issue of bank selection criteria in line with customers "e preference: why and how they select a particular bank to be served there. Although such studies have contributed substantially to the literature on bank selection, their findings may not apply to other countries like Ethiopia, due to differences in cultural, economic, and legal environments.

To the best of the researcher's knowledge, there is no previous research work in Ethiopia concerning the banking selection criteria of customers. Therefore, this study is particularly aimed to examine the determinants of customer's bank selection in the case of Addis Ababa city.

\section{Objectives of the study}

The overall objective of the study is to investigate the main determinants that affect customers' selection of banking services. And the specific objectives are as follows

+ To determine the criteria that customers consider important when selecting a bank and how those criteria are prioritized according to their importance.

$\downarrow$ To identify either any significant gender discrepancy among customers in the Selection of a bank or not.

+ To assess additional services required by customers in addition to the services currently offered by the bank of their choice.

\section{The research questions}

To achieve the objective of the study, the researcher has the following research questions.

a. What factors do customers consider important in selecting their choice of a bank and what are the most important factors?

b. Which bank(s) are the most preferred banks in Ethiopia based on the sample under consideration?

c. Which banking facilities are the most frequently used by customers?

d. Do customers have an intention to continue with their respective banks?

\section{Review of the related literature}

This chapter reviews the studies that have been carried out to date. Previous studies conducted in this area are organized based on their chronological context.

\subsection{Definition of terms}

A bank is an institution that deals in money and credit. It accepts deposits from the public and grants loans and advances to those who require funds for various purposes (Pilbeam, 2008). Banking is an activity that involves the acceptance of deposits to lend or invest. In addition to accepting deposits and lending funds, banking also involves providing various other services along with its main banking activity. These are mainly agency services but include several general services as well. A banker undertakes banking activities, accepting deposits and lending money for different purposes (Hart 2013).

\subsection{Customer's behavior}

Customer behavior is the process individuals or groups go through to select, purchase, use and dispose of goods, services, ideas or experiences to satisfy their needs and desires (Salon 2012). Consumer behavior is not only influenced by external factors, but also by their attitudes and expectations. These attitudes and expectations are constantly changing in response to a continuous flow of events, information, and personal experiences (Peer, 2016).

\subsubsection{Steps in the customer decision process}

Researchers realized those decision-makers possess a set of approaches ranging from careful analysis to pure to argue, depending on the importance of what they are utilizing and how much effort the person is willing to put into the decision. 


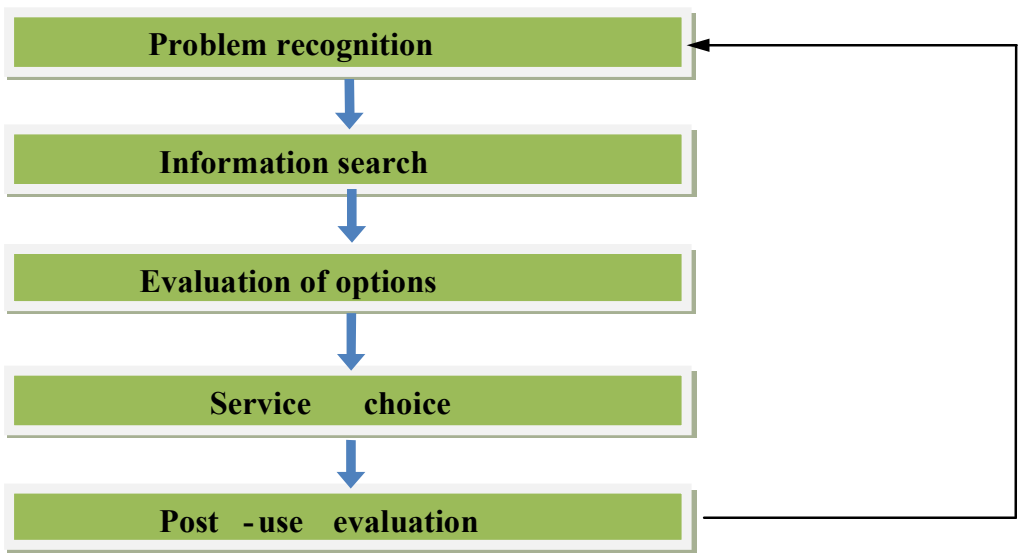

Figure 1: The customer decision-making process

Source: Adopted from ells (n.d.), pp. 157)

\subsubsection{Influences on customers' decisions}

Apart from understanding the procedure of the customer decision-making process, industries also try to determine what influences in customers" lives affect this process. Internal influences on customers' decisions: service giving organizations know that one customer's ideal treatment can be quite different from that of another customer. Perception is the process by which people select, organize and interpret information from the outside world (Sells, n.d.).

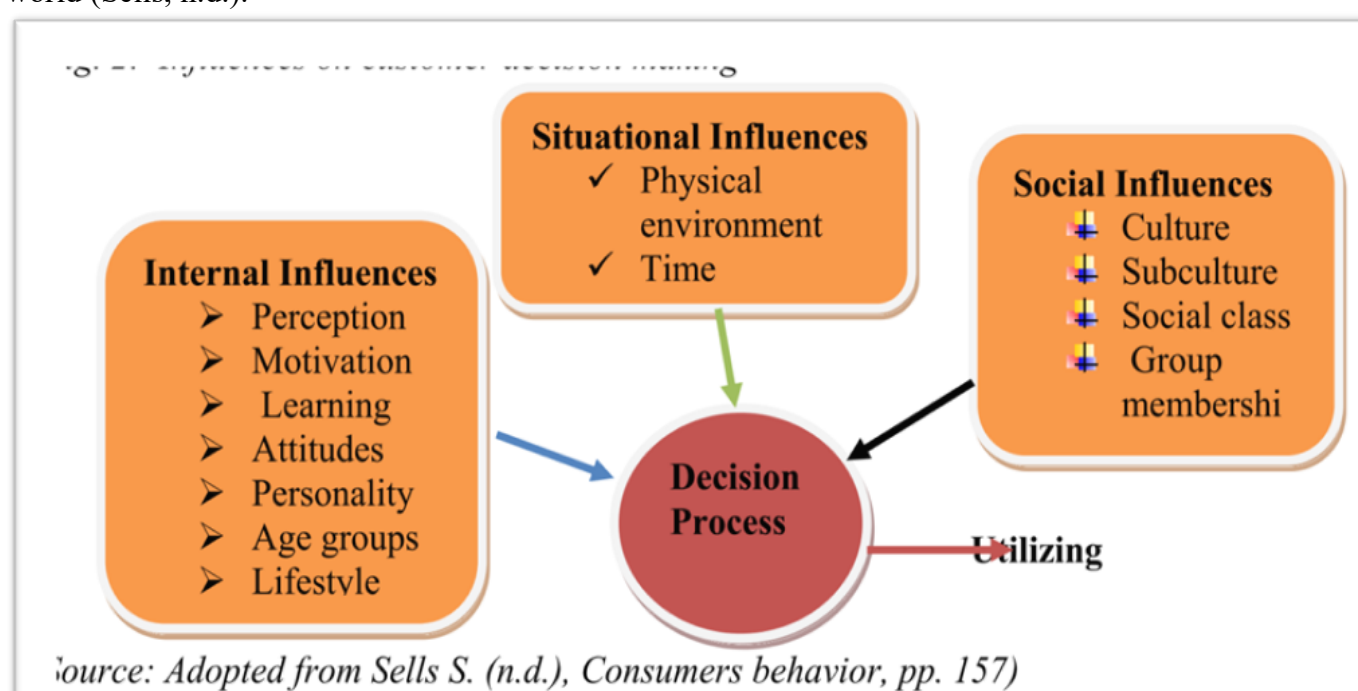

Figure 2: Influences on customer's decision making.

Several different factors in customers' lives influence the consumer decision-making process. Organizations need to understand these influences and which ones are important in the exploit process to make effective marketing decisions.

Situational influences on customers' decisions: these factors can affect what, where and how customers utilize their choices from different organizations. It is no secret that people's moods and behaviors are strongly influenced by their physical surroundings such as advertising. There is one motto by the advertising archives: "as customers are exposed to more and more advertising, advertisers must work harder than ever to get their attention" (Salon 2012).

\subsection{Customer's satisfaction}

Achieving customer satisfaction is strategic support to obtain long-term profitable growth. This may have its advantages and main results. For instance, more loyalty of customers can create a cross-selling \& up-selling of services/ products of one organization, great customer retention can result in a long customer lifetime value for the institution, better short and long term business performances are also consequences leading to a higher stock return, stock value and less volatile cash flow and long-period strong competitive positioning can lead to market 
leadership in one institution (Mokhlis et al., 2012).

\subsection{Bank selection criteria}

Various empirical research using different methodologies and approaches have been conducted in various parts of the world to investigate the bank selection criteria of the customers. Frequently these studies examined the question of why people prefer a specific bank. Among the researchers who did a scientific study on this topic were in Malaysia (Mokhlis et al. 2008, 2009 \& 2010; Haque et al., 2009), Nigeria (Maiyaki, 2008 \& 2011; Omar et al., 2006), Singapore (ta et al., 2000), Canada (Lévesque et al., 1996) and India (Rao et al., 2010). Eventually, the importance of the studies started more in direction of other features of bank choice, as the comparison of customers choice criteria for single and multiple bank users (Mokhlis et al., 2009) and analysis of the genderbased choice decision in banking (Omar et al., 2006; Mokhlis, 2009). And recently the variation in bank choice criteria between distinct cultural groups in Malaysia was investigated by( Mokhlis et al 2010).

Other researchers like, Lymperopoulos et al. (2006) examined the importance of service quality in bank selection and found four distinct factors as the main choice criteria that influence consumer'see bank choice. Bank service quality is the most important element that customers consider to select their mortgage providers and establish a long-term relationship with them. The other three refer to product attributes, access, and communication.

Mylonakis (2007) studied customer preferences in the home loans market experience of the bank customers in Greece. Promotion through television plays an important role and seems to affect the customer bank selection.

In Malaysia, Dusuki (2007) studied bank selection using self-administered questionnaires involving a sample of 750 respondents from four different regions. The most significant determinants perceived to be important for selecting banks were: convenient location, friendly employees, large, profit-minded, slow service, and efficient service.

Most recently, (Maiyaki 2017) in his survey in Nigeria obtained information about the factors determining the selection and preference of banks by retail customers. He used 417 sample bank customers using multi-stage sampling procedure and found that size of bank total assets, has the greatest influence on customer choice of banks, followed by availability of large branch network across the country, then the reputation of the bank, personal security of customer, and then convenient access to bank location.

\subsection{Gender-based difference in bank choice}

Previous studies listed gender differences as one of few demographic characteristics that determine the selection criteria employed by customers when selecting a bank. In the first major study of note, (Laroche et al. 2006) found that there are some significant differences in choice criteria for retail banks in Canada concerning basic demographic factors. Among the more interesting findings of this study were that males attached greater emphasis on overdraft privilege whereas females are more concerned with the friendliness of staff and safety of funds.

In Bahrain, Almossawi (2011) surveyed bank choice criteria and reported that male and female college students exhibited significant differences in 22 out of 30 bank selection factors. According to his findings, male students prefer banks based on: availability of parking space nearby, availability of ATMs in several locations, convenient ATM locations, banks reputation, and 24 hours availability of ATM service are the most important factors in selecting banks by female respondents.

In general, it can be concluded that even though there have been studies on bank selection criteria's in some developed and developing nations, as per the knowledge of the researcher, there appear to be no studies that examine the factors affecting customer preferences in banking services in Ethiopia. It is, therefore, not known whether the customers of the Ethiopian banks choose a bank based on proximity, effective service, banks reputation, friendliness of bank personnel, or any other criteria. In this context, the purpose of this study is to investigate the determinants affecting customers ${ }^{\text {ee }}$ section in banking services in Addis Ababa city

\section{Research design and Methodology 3.1 Research Methodology}

The choice of particular methodologies for the study depends upon the purpose of the study, the importance of information being collected, and the resources available for the researcher, and the skills of the researcher (Kothari, 2004). Accordingly, for this study both quantitative and qualitative methodologies are used, based on responses given by 201 customers in Addis Ababa city from different occupations (students, employees, and businessmen), are employed in the analysis.

\subsection{Research design}

The research design depicted below was used to study the determinants that affect customers' preferences in banking services among several banks. Survey questions of the questionnaire were gathered from various studies 
(Kaiyaki, 2011; Katircioglu et al., 2011; Rao, 2010; Mokhlis, 2009; Blank son et al., 2007; Cicic et al., 2004; Almossawi, 2001) in the relevant literature and revised and adapted to the Ethiopian banking system. This study was used the cross-sectional survey method because the data was collected at a point in time.

For the sample design used, see Figure 3.

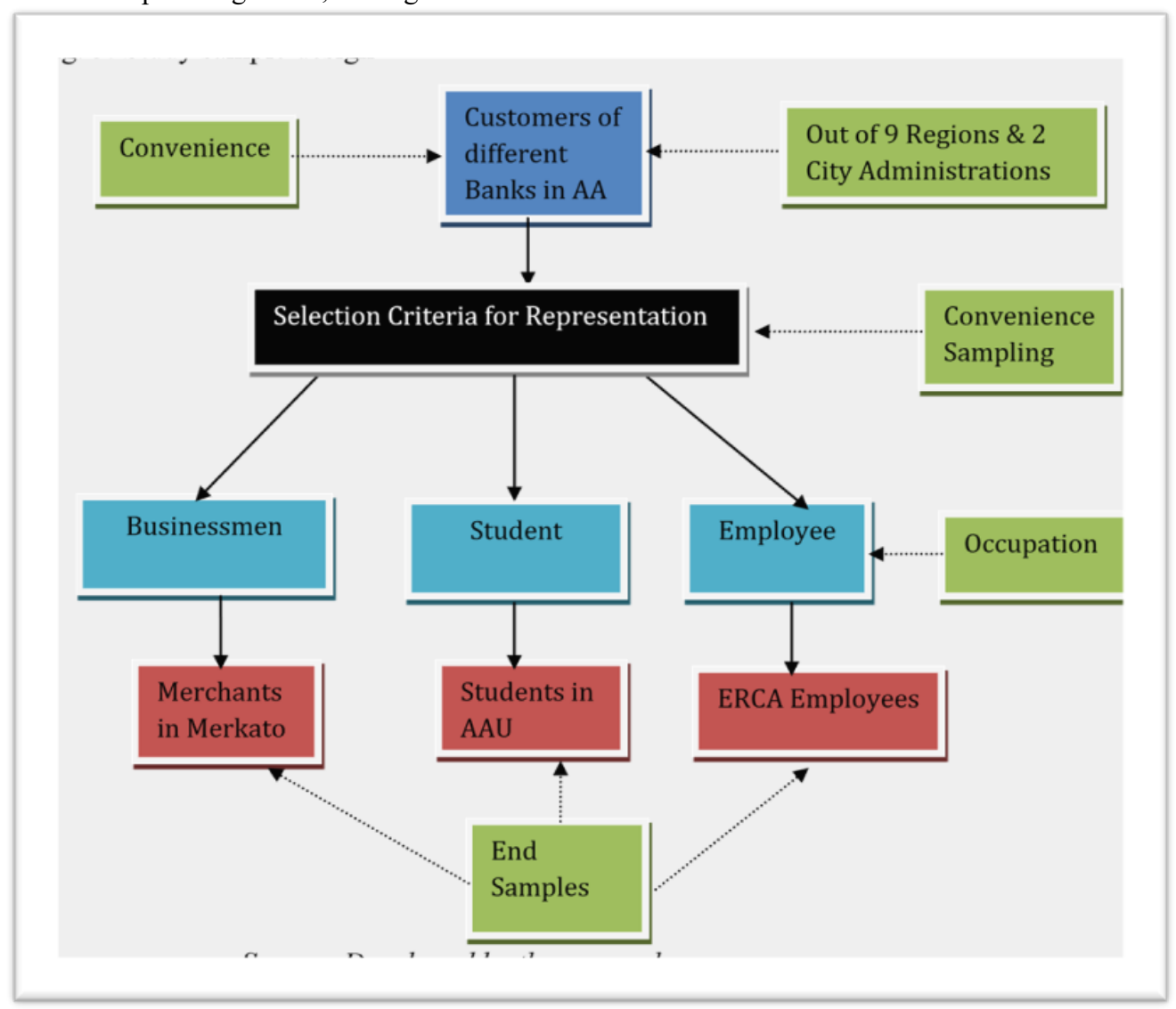

Figure 3: Research design, developed by the researcher.

\subsection{Source of data and sampling}

The target population for the study included students, businessmen, and employees living in Addis Ababa city. Forty-two percent of the respondents are students of AddisAbabaUniversity because of their convenience, 36 percent are employees from different regions of the Ethiopian revenues and customs authority, namely Bole, Gulale, and Mexico branches). These employees were selected based on the assumption that they can save and deposit money in banks because their salary is relatively attractive. While the remaining are businessmen from Merkato. These groups are expected to represent all types of population categories in the city while conducting an assessment of the determinants that affect customers' preferences in banking services.

\subsection{Questionnaire design}

It is the purpose of this study to understand determinants that affect customers' selection of banks using the design depicted in Figure 3. To achieve the research aim, the study was adopted the survey method through personally administered questionnaires including close-ended and open-ended questions.

The questions were organized into three sections as follows: the first section of the questionnaire asked respondents to obtain their background, questions regarding their gender, age, occupation, level of income, and so forth. The second section of the questionnaire sought to obtain information on the banking behavior of respondents. The respondents were asked for the name of banks at which banking services were used; which bank was the respondent's main bank and which was the respondent's subsidiary bank(s). The length of time that customers have been with their banks was also measured.

The final section of the questionnaire was designed to rate the relative importance of 24 bank attributes when choosing which banks to patronize. They were measured on a four-point Liker-type scale of importance ranging from ( $4=$ most important) to $(1=$ not important at all) as already mentioned in the reference above. 


\subsection{Data analysis and interpretation}

To determine the underlying dimensions in the set of bank selection criteria, the importance ratings for the evaluative criteria were factor analyzed. Factor analysis is a technique that is used to "reduce a large number of variables to some smaller number by telling the researcher which belongs together and which seems to say the same thing" (Field, 2005). This technique was believed to be appropriate for this particular analysis because banking selection determinants have many implications. The study was finally organized, summarized, and analyzed using STATA version 13.

\section{Data analysis and discussions}

From a total of 220 questionnaires distributed, 208 are returned with a response rate of 91.4 percent. Such a response rate is considered sufficient for statistical reliability and generalization (Mokhlis, 2009).

\subsubsection{Customers profile}

A summary of findings on customer's profiles along with three variables: age, level of income (average monthly income of the respondent), and level of education have been presented in table

\begin{tabular}{|c|c|c|c|c|c|}
\hline Variable & Categories & Frequency & Percent & Valid \%o & $\begin{array}{c}\text { Cumulative } \\
\text { \% }\end{array}$ \\
\hline Sex & Male & 155 & 77 & 77 & 77 \\
\hline Age & Female & 46 & 23 & 23 & 100 \\
\hline & Below 27 years & 106 & 52.7 & 52.7 & 52.7 \\
\hline & $27-35$ years & 57 & 28.4 & 28.4 & 81.1 \\
\hline & $36-45$ years & 32 & 15.9 & 15.9 & 97 \\
\hline \multirow{2}{*}{ Level of education* } & Above 45 years & 6 & 3 & 3 & 100 \\
\hline & Below preparatory & 9 & 4.5 & 4.5 & 4.5 \\
\hline & Preparatory completed & 20 & 10 & 10 & 14.5 \\
\hline & Diploma & 17 & 8.5 & 8.5 & 23 \\
\hline \multirow{2}{*}{ Level of income** } & Bachelor degree & 118 & 58.7 & 58.7 & 81.7 \\
\hline & Master and above & 37 & 18.3 & 18.3 & 100 \\
\hline & Lower than Br. 2, 000 & 42 & 20.9 & 20.9 & 20.9 \\
\hline & Br. 2, 001 to 4, 000 & 119 & 59.2 & 59.2 & 80.1 \\
\hline & Br. 4, 001 to 7, 000 & 33 & 16.4 & 16.4 & 96.5 \\
\hline
\end{tabular}

Table 1: Results of profile data of the respondents

Source: Computation from field survey data, 2018.

Note: *In Ethiopia, completion of preparatory school means the accomplishment of 12 years of schooling starting with class/grade 1 .

**1 us dollar $=31.7952$ Eth birr (as of May 9, 2018, as in all banks of Ethiopia,)

The respondents possess a high level of education. While 58.7 percent of the respondents have a bachelor's degree, 18.3 percent have attained either a master's or a Ph.D. degree. About 15 percent of the respondents have education at or below the preparatory school level. A similar study in Bangladesh (Khan et al., 2008) found 18.5 percent of the sample falling below the high school category.

The next table shows the proportion of customers' occupations based on their age distribution within each profession. 
Table 2: Distribution of respondents' Age by occupation

\begin{tabular}{|c|c|c|}
\hline Occupation & Number & Percentage \\
\hline Students: Male & 74 & $87 \%$ \\
\hline Female & 11 & $13 \%$ \\
\hline Employees: Male & 48 & $66.7 \%$ \\
\hline Female & 24 & $33.3 \%$ \\
\hline Businessmen: Male & 33 & $75 \%$ \\
\hline Female & 11 & $25 \%$ \\
\hline Total & 201 & $100 \%$ \\
\hline
\end{tabular}

Source: computation from field survey data, 2018.

As shown in Table 2, males account for about 66.7 percent, 75 percent, and 87 percent of the employee, businessmen, and student respondents respectively.

\subsubsection{Banking behavior of customers}

Accordingly, about 3 percent of the sampled customers are still users of non-bank services, ranging from microfinance institutions and other traditional saving ways (Edir \&Equib).

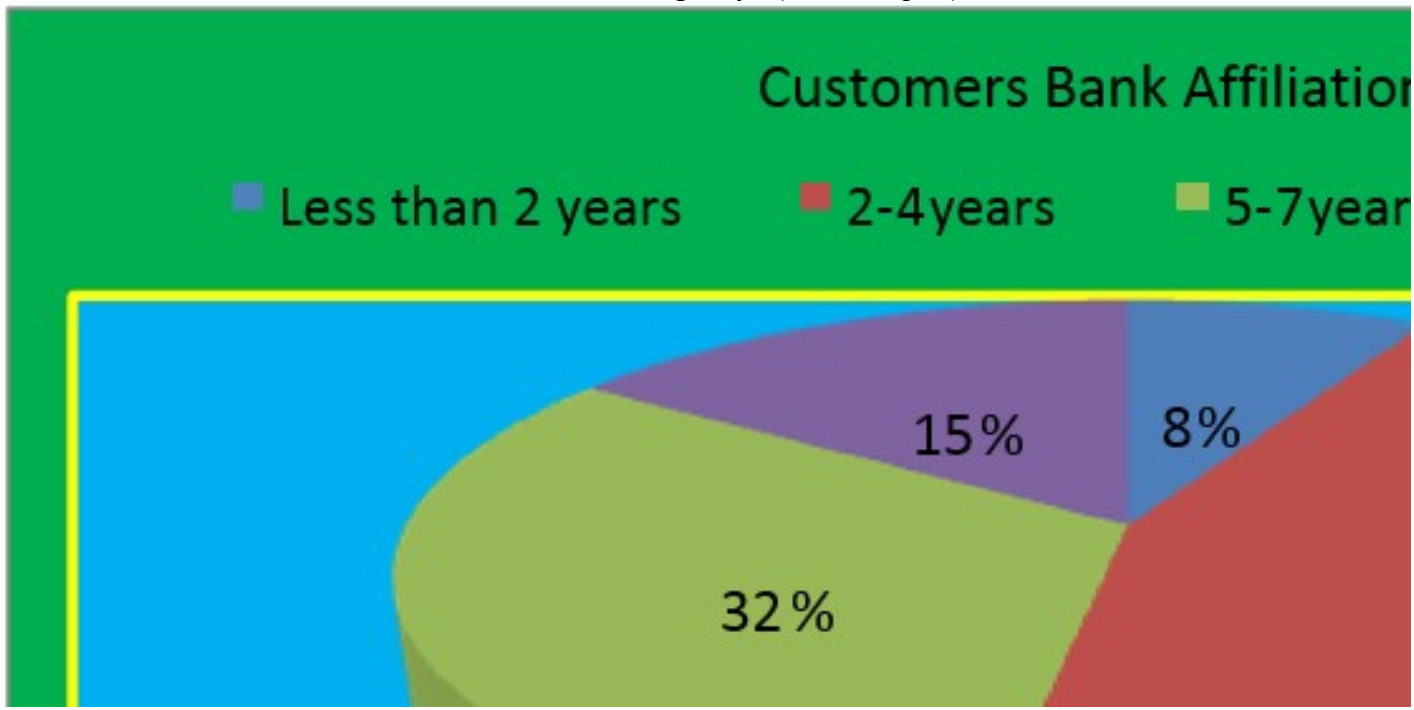

Figure 4: Respondents bank affiliation period

Source: Computation from Field survey data, 2018

As demonstrated in figure 4, about 47 percent of the respondents have more than five years of banking relationship with their main bank. Such a long permanent status of relationship indicates the capability of customer retention by the banks. This is followed by 45 percent of the customers with an experience of two to four years. Eight percent of the customers have a short period relationship (less than two years) with their respective banks.

Ethiopian banks are different. Table 3 revealed that the commercial bank of Ethiopia (CBE), Dashen bank (DB), and Wegagen bank (wb) are the three most preferred banks by the respondents in Addis Ababa respectively. 
Table 3: Rank of banks used by the respondents

\begin{tabular}{|c|c|c|c|}
\hline List of Banks & Frequency & Percentage & Rank \\
\hline Commercial Bank of Ethiopia(CBE) & 146 & 72.6 & 1 \\
\hline Dashen Bank (DB) & 60 & 29.9 & 2 \\
\hline Wegagen Bank (WB) & 26 & 12.9 & 3 \\
\hline Awash International Bank (AIB) & 25 & 12.4 & 4 \\
\hline Nib International Bank (NIB) & 15 & 7.5 & 5 \\
\hline United Bank (UB) & 14 & 7 & 6 \\
\hline Bank of Abyssinia (BOA) & 14 & 7 & 6 \\
\hline Lion International Bank (LIB) & 3 & 1.5 & 8 \\
\hline Cooperative Bank of Oromia (CBO) & 2 & 1 & 9 \\
\hline Construction and Business Bank (CBB) & 1 & 0.5 & 10 \\
\hline
\end{tabular}

Source: Computation from field survey data, 2018.

The results show that about 50 percent of the respondents need other services than the services offered now.

4.1.3 Customers' usage of banking services

Table 4 shows the proportion of respondents that are using different bank products or services as accessible in Addis Ababa. A high level of customer awareness and tradition of saving accounts and local money transfer services has been observed as the basic types of customer'se habit of banking services.

Table 4: Respondents Usage of Banking Services

\begin{tabular}{|l|l|l|}
\hline Type of Service & Number of Users & Percentage \\
\hline Current account & 58 & 28.9 \\
\hline Saving account & 142 & 70.7 \\
\hline Loan facilities & 1 & 0.5 \\
\hline Money transfer services & 87 & 42.3 \\
\hline ATM services & 25 & 12.4 \\
\hline
\end{tabular}

Source: computation from field survey data, 2018

\subsection{Explanation of bank selection factors}

A Principle Component Analysis (PCA) was carried out using the eigenvalue greater than one rule, seven factors are identified. All characteristics with factor loadings of 0.40 and above are retained. In addition, means were computed for all attributes retained within each factor to identify the relative importance of such attributes to the customers in their bank selection process. In terms of overall factor means, the sixth factor is the most important in terms of bank selection and the first factor is (slightly) the least important. 
Table C1: KMO and Bartlett's Test

\begin{tabular}{|c|c|c|}
\hline Kaiser-Meyer-Olkin Measur & of Sampling Adequa & .802 \\
\hline Bartlett's Test of Sphericity & Approx. Chi-Square & 1372.442 \\
\hline & Df & 276 \\
\hline & Sig- & .000 \\
\hline
\end{tabular}

\section{Table C2: Total Variance Explained}

\begin{tabular}{|c|c|c|c|c|c|c|c|}
\hline \multirow{2}{*}{$\begin{array}{l}\text { 픙 } \\
\text { 夏 }\end{array}$} & \multicolumn{3}{|c|}{ Initial Eigenvalues } & \multicolumn{3}{|c|}{$\begin{array}{c}\text { Extraction Sums of Squared } \\
\text { Loadings }\end{array}$} & Rotatio \\
\hline & Total & $\begin{array}{c}\% \text { of } \\
\text { Variance }\end{array}$ & $\begin{array}{l}\text { Cumula } \\
\text { tive } \%\end{array}$ & Total & $\begin{array}{c}\% \text { of } \\
\text { Variance }\end{array}$ & $\begin{array}{l}\text { Cumula } \\
\text { tive } \%\end{array}$ & Total \\
\hline 1 & 5.667 & 23.612 & 23.612 & 5.667 & 23.612 & 23.612 & 3.768 \\
\hline 2 & 2.163 & 9.011 & 32.624 & 2.163 & 9.011 & 32.624 & 2.416 \\
\hline 3 & 1.624 & 6.766 & 39.390 & 1.624 & 6.766 & 39.390 & 1.967 \\
\hline 4 & 1.470 & 6.124 & 45.514 & 1.470 & 6.124 & 45.514 & 1.919 \\
\hline 5 & 1.221 & 5.088 & 50.602 & 1.221 & 5.088 & 50.602 & 1.607 \\
\hline 6 & 1.167 & 4.864 & 55.466 & 1.167 & 4.864 & 55.466 & 1.390 \\
\hline 7 & 1.014 & 4.224 & 59.690 & 1.014 & 4.224 & 59.690 & 1.259 \\
\hline 8 & .926 & 3.859 & 63.549 & & & & \\
\hline 9 & .911 & 3.795 & 67.344 & & & & \\
\hline 10 & .846 & 3.524 & 70.868 & & & & \\
\hline 11 & .784 & 3.266 & 74.134 & & & & \\
\hline 12 & .734 & 3.059 & 77.194 & & & & \\
\hline 13 & .673 & 2.806 & 80.000 & & & & \\
\hline 14 & .654 & 2.726 & 82.726 & & & & \\
\hline 15 & .579 & 2.411 & 85.136 & & & & \\
\hline 16 & .556 & 2.317 & 87.453 & & & & \\
\hline 17 & .509 & 2.119 & 89.573 & & & & \\
\hline 18 & -486 & 2.024 & 91.597 & & & & \\
\hline
\end{tabular}

The first factor in Table 5 explains a selection factor based on the low-interest rate on loans, the highinterest rate on savings, attractive interest within a short period, and the e-banking facilities. This factor accounts for 15.70 percent of the total variance. This factor may be labeled a financial benefits/ technology factor. Here, it can be noticed that low service charge $($ mean $=2.0945)$ and attractive interest within a short period $(\operatorname{mean}=$ 2.0896) have the two highest means in this factor, indicating the vast importance of service charges and interest rate in determining bank selection for customers. 
Table 5: Results of factor analysis

\begin{tabular}{|c|c|c|c|}
\hline Factors and Items & Factor loadings & Eigenvalues $^{1}$ & $\begin{array}{c}\text { \% of } \\
\text { Variance }^{2}\end{array}$ \\
\hline \multicolumn{4}{|l|}{ Factor 1: Financial benefits/ technology } \\
\hline $\begin{array}{l}\text { The low-interest rate on loans } \\
\text { High interest rate on savings } \\
\text { Attractive interest within short period of time } \\
\text { Phone banking facility } \\
\text { Internet banking facility } \\
\text { Low service charge } \\
\text { Factor 2: Service provision }\end{array}$ & $\begin{array}{l}.787 \\
.784 \\
.635 \\
.613 \\
.593 \\
.561\end{array}$ & 5.667 & 15.700 \\
\hline $\begin{array}{l}\text { Good customer services } \\
\text { Bank has speedy services } \\
\text { Reception at the bank } \\
\text { A variety of services are offered } \\
\text { Factor 3: Employer's influence }\end{array}$ & $\begin{array}{l}.831 \\
.745 \\
.633 \\
.417\end{array}$ & 2.163 & 10.067 \\
\hline $\begin{array}{l}\text { My employer used the same bank } \\
\text { Extended operation hours } \\
\text { Availability of ATM services } \\
\text { Factor 4: Reputation }\end{array}$ & $\begin{array}{l}.651 \\
.643 \\
.591\end{array}$ & 1.624 & 8.197 \\
\hline $\begin{array}{l}\text { Establishment time of the bank (oldest) } \\
\text { Bank's reputation } \\
\text { Being a government owned bank } \\
\text { Factor 5: Promotion strategy }\end{array}$ & $\begin{array}{l}.695 \\
.633 \\
.585\end{array}$ & 1.470 & 7.994 \\
\hline $\begin{array}{l}\text { Advertising via mass media } \\
\text { Availability of several branches } \\
\text { Availability of parking space nearby } \\
\text { Factor 6: Convenience/ security }\end{array}$ & $\begin{array}{l}.698 \\
.546 \\
.511\end{array}$ & 1.221 & 6.697 \\
\hline $\begin{array}{l}\text { Proximity to home and/ or workplace } \\
\text { Security arrangement of the bank } \\
\text { Factor 7: Bank image }\end{array}$ & $\begin{array}{l}.792 \\
.411\end{array}$ & 1.167 & 5.791 \\
\hline $\begin{array}{l}\text { Pleasant bank environment } \\
\text { The external appearance of the bank }\end{array}$ & $\begin{array}{l}.778 \\
.528\end{array}$ & 1.014 & 5.245 \\
\hline
\end{tabular}

Source: computations from the field survey data, 2018

The analysis from Table 5 yielded a seven principal components solution, which together explained more than half of the variance observed in the variables (59.69 percent), which satisfies the percentage of variance criterion for social science research.

\subsection{Ranking importance of bank selection factors}

To analyze differences in the importance of bank selection criteria employed, a ranking table was produced showing the mean score of each factor. Table 6 presents findings concerning the relative importance of bank selection criteria factors. The top two factors that found in the listing were "convenience/ security" (mean= 3.2513 ) and "service provision" (mean=3.1008). The significance of the convenience factor has been seen in previous studies which have used students and other customers as their sample (Scram, 2011; Holstius et al., 2005; Owusu- Frimpong, 2009; Lee and Marlowe, 2013; Dusuki, 2007 and Katircioglu et al., 2011).

1 The average variance is explained in the items by a component multiplied by the number of components. An eigenvalue of 1 is equivalent to the variance of 1 item.

2 These represent the percentage of the total variance in the items explained by a component. This is equivalent to the eigenvalue divided by the number of items. 
Table 6: ranking importance of bank selection criteria factors

\begin{tabular}{|l|l|l|}
\hline Factors & Mean & Rank \\
\hline Convenience/ security & 3.2513 & 1 \\
\hline Service provision & 3.1008 & 2 \\
\hline Employers' influence & 2.5937 & 3 \\
\hline Bank image & 2.5538 & 4 \\
\hline Promotion strategy & 2.2604 & 5 \\
\hline Reputation & 2.1841 & 6 \\
\hline Financial benefits/ technology & 1.9544 & 7 \\
\hline
\end{tabular}

Based on a four-point Likert scale $4=$ very important; $1=$ not important

As opposed to the study by Almossawi (2001) in which technology-related facilities and financial benefits ranked as the topmost important selecting criteria for banks, in this study, these factors (mean=1.9544) were found to be the last and least important criteria in the selection of banks by the customers.

\subsection{Gender-based ranking of importance}

Optical examination of Table 7 reveals that „convenience ${ }^{e e}$ is most important in the selection decision of both male and female respondents, being in the top criteria in each case. Male respondents ranked „,bank image ${ }^{\text {ee }}$ as the second most important factor but ranked third by female respondents. On the other hand, service provision is ranked second by female respondents while male respondents ranked this factor as third. Female respondents ranked "secure feeling"e as their fourth most significant factor in selecting banks and banking services. There are some similarities between the findings of this study and the findings of earlier studies. The selection of "convenience"e as the most important factor in selection decision by male and female respondents is acknowledged in the literature (Holstius and Kaynak, 2005; Owusu-frimpong, 2009; Lee and Marlowe, 2013).

Table 7: Ranking importance of bank selection factors by gender

Selection Factors Male Female

\begin{tabular}{|l|c|c|c|c|}
\hline & Mean & Rank & Mean & Rank \\
\hline Convenience & 3.1871 & 1 & 3.7391 & 1 \\
\hline Bank image & 3.1742 & 2 & 2.6304 & 3 \\
\hline Service provision & 3.0823 & 3 & 3.1630 & 2 \\
\hline Employers' influence & 2.6301 & 4 & 2.4783 & 5 \\
\hline Reputation/ promotion strategy & 2.0215 & 5 & 2.1232 & 6 \\
\hline Attractiveness & 1.8860 & 6 & 1.4891 & 8 \\
\hline Financial benefits/ technology & 1.8771 & 7 & 1.8406 & 7 \\
\hline Secure feelings & & & 2.6191 & 4 \\
\hline
\end{tabular}

Based on four-point Likert scale 4 = very important; 1 = not important at all

\section{9 Ranking of importance by occupation and their explanation}

A Principle Component Analysis (PCA) was carried out using the eigenvalue greater than one rule, seven factors by the employees and students, and eight factors by the businessmen are identified. All characteristics with factor loadings of 0.40 and above were retained. In addition, means are computed for all attributes retained within each factor to identify the relative importance of such attributes to the customers in their bank selection process.

Items falling within factor one mainly include questions like; high-interest rate on saving, low internet rate on loans, attractive interest within a short period, and low service charge for both employee and student respondents. This factor may be reduced to the common denominator "financial benefits" while "technology" related questions such as internet and phone banking facilities were grouped under factor one for businessman respondents. 
Table 8: Ranking importance of bank selection factors among different occupation

\begin{tabular}{|c|c|c|c|c|c|c|}
\hline \multicolumn{7}{|c|}{ Businessmen } \\
\hline & Mean & Rank & Mean & Rank & Mean & Rank \\
\hline Convenience & 3.3472 & 1 & 2.4902 & 3 & 3.6705 & 1 \\
\hline Service provision & 3.1759 & 2 & 3.0376 & 2 & 2.2557 & 4 \\
\hline Bank's image & 3.0833 & 3 & 3.1059 & 1 & 3.3409 & 2 \\
\hline Technology & 2.3889 & 4 & 2.0628 & 5 & 1.3561 & 8 \\
\hline Reputation & 2.3380 & 5 & 2.0118 & 7 & 1.9470 & 5 \\
\hline Promotion strategy & 2.1759 & 6 & 2.2392 & 4 & 1.8636 & 6 \\
\hline Financial benefits & 2.0972 & 7 & 2.0235 & 6 & 1.4925 & 7 \\
\hline Secure feelings & & & & & 2.9546 & 3 \\
\hline
\end{tabular}

Based on four-point Likert scale 4 = very important; 1 = not important at all

The three most important factors considered by employees and student customers when selecting a bank are "convenience", "service provision" and "bank image". However, the convenience factor is considered as a first choice by employees ${ }^{\text {ee }}$ hence third most important factor by students and bank image was the most essential factor by students as ranked third by employees. The first two findings of this study are consistent with previous studies (Haron et al., 2014).

\subsection{Conclusion}

Today, the existence of solid competition among banks necessitates a detailed understanding of the influential factors behind the bank selection decision in Addis Ababa city. Therefore, the objective of this research is to investigate the determinants of bank selection decisions based on their importance and identify the additional services needed by customers other than the currently offered services. To trace such objectives, we used a convenience sampling procedure comprising 201 observations. The sample size comprises 85 students, 72 employees, and 44 merchants in the city.

Descriptive analysis revealed that most respondents fall in the age group of below 27 years. Concerning their education, about 77 percent of the sample respondents have attained at least a first degree. In talking about bank selection by customers, the level of income of the respondents matters more. In this regard, the results show that about 21 and 59 percent of the respondents received a monthly income of less than Eth birr 2,000 and 2, 000 to 4,000 . This is followed by a very few individuals -33 and 7 respectively - that have an average income of etb 4,000 to 7,000 and above 7,000 .

An important issue in dealing with bank selection is to see the affiliation of respondents with the respective bank(s). Results show that about 8 percent of the customers have less than two years of experience of getting service with a particular bank. The majority of them - about 45 percent- have indicated a relationship that lasts for 2 to 4 years.

Furthermore, 32 percent and 15 percent of the beneficiaries report as having a 5 to 7 and more than 7 years affiliation range respectively.

The researcher observe that the commercial bank of Ethiopia, Dashen bank, Wegagen bank, and Awash bank are the topmost preferred banks by customers. Users frequently choose the two former banks perhaps because of their wider operation and quality of service provision respectively.

The factor analysis results revealed that convenience, service provision, and employerse influence as fundamental determinants of bank selection, among others. Finally, differences in bank choice are examined from the gender perspective. The finding demonstrates that while there exists no variation across males and females due to convenience, we see that males prefer bank image to service provision. The reverse holds for female customers in Addis Ababa city.

\subsection{Recommendations}

Based on the findings of the study, we forward the following recommendations.

- Customers place more emphasis on factors like convenience, service provision, employers' influence, and bank image. Therefore, such factors should be considered seriously by the commercial banks in designing their marketing strategies by widening their branches and providing good customers services to customers.

+ Customers suggest some additional improvements in the banking industry other than the services currently offered. Consequently, focusing on the well-integrated application of technology and staff through operations that respond to customer needs encourages customers to use a whole range of banking services rather than just a few. It also helps to build loyalty by creating deeper and fuller customer relationships.

+ Since the age category below 27 is the most salient and with more representation in the sample, banks 
should target their marketing mix toward this category. Such a technique will ensure attraction of jobmarket entering people towards bank service and also retention of the people who are likely to remain long-term loyal customers. In addition, banks should try to find out some ways to better familiarize their customers with the borrowing products for customers.

+ Though about 50 percent of the customers report as satisfied, banks should keep their customers more satisfied with the services provided. Based on the results of this study, customer satisfaction and loyalty would be increased by focusing on different, but related, factors: bank service processes, including well-experienced bank personnel, inter-bank networking, and service facilities required conditions for receiving the needed services, internet banking facilities, and speed facilities.

+ Finally, bank management should be aware that some of the bank selection determinants differ from one segment to another in the business firm market. These results would enable bank managers to identify the important bank attributes that affect bank selection decisions made by each segment in the business market in Ethiopia.

+ Since the results of this study are based on customerse perceptions only, investigating the correspondence between consumers"e and service providers" perceptions could be an important research area among interested future researchers. This will help the industry to better understand whether both customers and banks have the same perceptions regarding issues relevant to bank selection criteria.

+ In addition, future researches should explore the bank image dimensions which customers perceived as applicable to their selection decision, emphasizing the choice between private and public banks in support of Condition.

\section{References}

Abduh M., Omar M. A. (2010), Who Patronizes Islamic Banks in Indonesia, The International Conference on Business and Economics, April 15-16, Andalas University, Indonesia.

Abraha S.L \& Imam S.H. (2005), Dashen Bank as an Information Infrastructure First Deliverable: INF5210.

Almossawi, M. (2011), Bank Selection Criteria Employed by College Students in Bahrain: An Empirical Analysis International Journal of Bank marketing v5 p,112-25

Anderson, W.T., Jr., Cox, E.P. and Fulcher, D.G. (1976), Bank Selection Decision and Market Segmentation, Journal of Marketing, Vol. 40, pp. 40-5.

Blankson C., Cheng J., \& Spears N. (2017), Determinants of Banks Selection in the USA, Taiwan, and Ghana: International Journal of Bank Marketing, Vol.25, No 7,pp499-489.

Blankson C., Omar O. E., and Cheng J. M. (2002), The Retail Bank Selection in Developed and Developing Countries: A Cross-National Study of Students' Bank- Selection Criteria, Thunderbird International Business Review Vol. 51, No. 2, pp. 183-98

Cicic M., Brkic N. and Agic E. (2004), Bank Selection Criteria Employed by Students in a Southeastern European Country: An Empirical Analysis of Potential Market Segments' Preferences; University of Sarajevo.

Debasish S. S., Sarma S., and Shil N. C. (2011), A Study on Customer Delight in Selected Commercial Banks in India, International Journal of Contemporary Business Studies Vol: 2, No: 2, ISSN 2156-7506.

Devlin, J.F. (2002), Customer Knowledge and Choice Criteria in Retail Banking: Journal Of Strategic Marketing, Vol. 10 No. 4, pp. 273-90.

Devlin, J.F. and Gerrard, P. (2004), Choice Criteria in Retail Banking: An Analysis of Trends, Journal of Strategic Marketing, Vol. 12 No. 1, pp. 13-27.

Dusuki A. W. and Abdullah N. I. (2007), Why do Malaysian Customers Patronize Islamic banks? International Journal of Bank Marketing Vol. 25 No. 3, pp. 142-160.

Feldman, M.S. (1995), Strategies for Interpreting Qualitative Data, Qualitative Research Methods: Series 33, Sage Publications, Thousand Oaks, CA.

Field, A. P. (2005), Research Methods: Discovering statistics using SPSS, second edition, London, sage. Gerrard, P. \& Cunningham, J. B. (2001), Singapore Undergraduates: How They Choose which Bank to Patronize: International Journal of Bank Marketing, 19(3), 104-114.

Hair, J. F. Jr., Anderson, R. E., Tatham, R. L. and Black, W. C. (1998), Multivariate Data Analysis. 5th ed., Englewood Cliffs, NJ: Prentice-Hall.

Halsbury H. S. G., Walter F. M. and Mugford K. H. (1978), Halsbury's Laws of England: cumulative supplement, Vol. 20 to 43, 3rd edition, Volume 2, ISBN $0406031738,9780406031730$.

Hamel, G. and Prahalad, C.K. (1994), Computing for the Future, Harvard Business School Press, Boston, MA.

Haque, A.; Osman J. and Ismail A. Z. H. (2009), Factor Influences Selection of Islamic Banking: A Study on Malaysian Customer Preferences, American Journal of Applied Sciences 6 (5): 922-928, ISSN 1546-9239, 
Science Publications.

Haron, S., Ahmad, N., \& Planisek S. L. (1994), Bank Patronage Factors of Muslim and non-Muslim Customer International Journal of Bank Marketing, 12(1), 33-40.

Hart, H.L. (1931), The Law of Banking: 4th ed. Vol. 1.

Holstius K. and Kaynak K. (1995), Retail Banking in Nordic Countries: The Case of Finland, International Journal of Bank Marketing Vol. 13, No . 8, pp. 10-20.

Jeromy, A. (2007), Research Methods, Cluster Analysis \& Factor Analysis, Pp. 325-711

Kaynak, E. \& Kucukemiroglu, O. (2002), Bank and Product Selection: Hong Kong. International Journal of Bank Marketing, 10(1), 3-16.

Kaynak, E., Kucukemiroglu, O. and Odabasi, Y. (1991), Commercial Bank Selection in Turkey, International Journal of Bank Marketing, Vol. 9 No. pp. 30-9.

Keillor, B.D. and Hult, G.T.M. (1999), A Five Country Study of National Identity: Implications for International Marketing Research and Practice, International Marketing Review, Vol. 16 No. 1, pp. 65-82.

Kennington C., Hill J., and Rakowska A. (1996), Consumer Selection Criteria for Banks in Poland, International Journal of Bank Marketing 14/4, 12-21.

Khan M. S. N., Hassan M.K. \& Shahid A. I. (2008), Banking Behavior of Islamic Bank Customers in Bangladesh, Journal of Islamic Economics, Banking

and Finance, pp. 161-94.

Khattak N.A \& Rehman K.U. (2010), Customer Satisfaction and Awareness of Islamic Banking System in Pakistan, African Journal of Business Management Vol. 4(5), pp. 662-671, May 2010.

Khazeh, K. \& Decker, W. H. (1992-93), How Customers Choose Bank: Journal of Retail Banking, 14(4), 41-44.

Kotler, P. (2000), Marketing Management: The millennium ed., Prentice-Hall, Upper Saddle River, NJ.

Kumar M, Kee F. T., \& Charles V. (2010), Comparative Evaluation of Critical Factors in Delivering Service Quality of Banks: An Application of

Dominance Analysis in Modified SERVQUAL Model, International Journal of Quality \& Reliability Management Vol. 27 No. 3, pp. 351-377.

Laroche, M., J. Rosenblatt and T. Manning (1986), Services Used and Factors Considered Important in Selecting a Bank: An Investigation Across Diverse Demographic Segments International Journal of Bank Marketing, Volume 4, No. 1, pp. 35-55.

Lee, J. and Marlowe, J. (2003), How Consumers Choose a Financial Institution: Decision-Making Criteria and Heuristics: International Journal of Bank Marketing, 21/2, pp. 53-71

Maiyaki, A.A. (2011); Factors Determining Bank's Selection and Preference in Nigerian Retail Banking, International Journal of Business and Management Vol. 6, No. 1, Pp. 253-57.

Maiyaki A. A., \& Mokhtar, S.S.M. (2010), Effects of Electronic Banking Facilities, Employment Sector and Age-Group on Customers' Choice of Banks in Nigeria, Journal of Internet Banking and Commerce, vol. 15, no.1.

Mauri, A. (2003), Origins and Early Development of Banking in Ethiopia: Working Paper n.04.2003, Marzo, Milano.

Mokhlis, S. (2009), Determinants of Choice Criteria in Malaysia's Retail Banking: An Analysis of GenderBased Choice Decisions, European Journal of Economics, Finance and Administrative Sciences ISSN 1450- 2887 Issue 16, pp. 18-30.

Mokhlis S., Mat N. \& Salleh H. (2008), Commercial Bank Selection: the case of undergraduate students in Malaysia, the international review of Business Research Papers, vol. 4 No. 5, pp. 258-70

Mokhlis S., Mat N. Salleh H. (2010), Ethnicity and Choice Criteria in Retail Banking: A Malaysian Perspective, International Journal of Business and Management Vol. 5, No. 6; June 2010.

Mokhlis S., Salleh H., \& Mat N. (2009), Commercial Bank Selection: Comparison between Single and Multiple Bank Users in Malaysia,

European Journal of Economics, Finance and Administrative Sciences - Issue 16, vol. 1 No. 2 pp. 263-73.

Mols N. P., Bukh P. N. D. and Blenker P. (1997), European Corporate Customers' Choice of Domestic Cash Management Banks, International Journal of Bank Marketing 15/7 [1997] 255-263

Munusamy J., Chelliah S., and Mun H.W. (2010), Service Quality Delivery and Its Impact on Customer Satisfaction in the Banking Sector in Malaysia; International Journal of Innovation, Management and Technology, Vol. No. 4, pp. 3998-404.

Mylonakis, J. (2017); A Research Study of Customer Preferences in the Home Loans Market: The Mortgage Experience of Greek Bank Customers, International Research Journal of Finance and Economics ISSN 1450- 2887 Issue 10, pp. 153-66

Owusu-Frimpong N. (2009), Patronage Behavior of Ghanaian Bank Customers, International Journal of Bank Marketing 17/7 [1999] 335-341, South

Bank University, London, UK 
Parker \& Maurice Megrah (1972), Paget's Law of banking: 8th edition, pp. 1-10.

Peer, V. (2009), Bank Choices in Economic Recession: A study of the influence of the financial crisis on customer choice behavior in the banking sector, Erasmus School of Economics, Master Thesis.

Rao, A. S. (2010), Bank Selection Criteria Employed by MBA Students in Delhi: An Empirical Analysis, Journal of Business Studies Quarterly, Vol. 1, No. 2, pp. 56-69

Rehman, H. \& Ahmed S. (2008), An Empirical Analysis of the Determinants of Bank Selection in Pakistan: A Customer View, Pakistan Economic and Social Review Volume 46, No. 2, pp. 147-160.

Safakli O. V. (2007), A research on the Basic Motivational Factors in Consumer Bank Selection: Evidence from Northern Cyprus, Banks and Bank Systems, Volume 2, Issue 4, pp. 93-100

Sanyang, L. (2009), Bank Strategic Positioning and Factors for Bank Selection: A case of The Gambia, a Master thesis, Ming Chuan University.

Schram, J. (1991), How Student Choose their Banks: US Banker, 110, 75-78. Sells M. R. (n.d.), Consumers Behavior Real People, Real Decisions: Decision time at Electrolux, pp. 176-83.

Senyücel E. M.S (n.d.), Bank Selection Criteria in the Cypriot Banking Industry: Eastern Mediterranean University Famagusta, Turkish Republic of Northern Cyprus via Mersin 10, Turkey.

Shaher T. A., Kasawneh O., and Salem R. (2011), The Major Factors that Affect Banks' Performance in Middle Eastern Countries, Journal of Money, Investment and Banking ISSN 1450-288X Issue 20, pp. 101-09

Ta, H.P., and Har, K.Y. (2000), A Study of Bank Selection Decisions in Singapore using the Analytical Hierarchy Process: International Journal of Bank Marketing, 18, 170-180.

Thwaites, D. \& Vere, L. (1995), Bank Selection Criteria: A Student Perspective.Journal of Marketing Management, 11(1-3), 133-149.

Ulengin B. (1998), Using Hierarchical Information Integration to Examine Customer Preferences in Banking, International Journal of Bank Marketing 16/5 202-210.

Worku, G. (2010), Electronic-Banking in Ethiopia- Practices: Opportunities and Challenges, Journal of Internet Banking and Commerce, August 2010, vol 15, no 2

Yue, H. and Tom, G. (1995), How the Chinese Select their Banks: Journal of Retail Banking, Vol. XVI No. 4, winter. Zineldin, M. (1996); Bank Strategic Positioning and Some Determinants of Bank Selection: International Journal of Bank Marketing, 14 (6), 12-22. 